\title{
Communication
}

[Comunicação]

\section{Squamous cell carcinoma in vaginal fundus in a Brahman cow}

[Carcinoma de células escamosas no fundo do saco vaginal de uma vaca Brahman]

\author{
A. Pimenta-Oliveira, J.P. Oliveira-Filho*, D.Q. Cagnini, P.R. Badial, E. Cisneros-Álvarez, \\ R. Laufer-Amorim, N.C. Prestes \\ Faculdade de Medicina Veterinária e Zootecnia - UNESP \\ Campus de Botucatu - Rubião Jr. \\ 18618-970 - Botucatu, SP
}

The squamous cell carcinoma (SCC) is a malignant keratinocytes tumor associated to long exposure to ultraviolet (UV) light, unpigmented epidermis and lacking or small number of hair on the affected region (Ramos et al., 2007). Unpigmented mucocutaneous folds showed a higher risk for SCC, mainly in white-haired cattle (Galera and Martins, 2001). SCC may also be triggered by chronic irritation of cutaneous wounds leading to tissue metaplasia (Kusewitt and Rush, 2007).

In Brazil, SCC is the most common neoplasm reported in cattle (30.6\%), usually observed on the periocular (23.3\%) and vulvar (23.3\%) regions (Ramos et al., 2007). When in the female genital tract, SCC often affects the vulva, due to the exposure of the epidermis which is unpigmented and have no hair to UV light (Ramos et al., 2007). Therefore the aim of this article is to describe the clinical findings and the immunohistochemical evaluation of p53 and Ki67 in squamous cell carcinoma in vaginal fundus in a cow.

A Brahman cow, 12-years-old, raised under an intensive system in a farm (S:23 $04^{\prime} 34.7^{\prime \prime} / \mathrm{W}$ : $\left.48^{\circ} 27^{\prime} 12.2^{\prime \prime}\right)$ located in the State of São Paulo, was evaluated during 30 months. Data obtained from the animal's reproductive files indicated two parturitions, at three and five years of age. 17 transvaginal follicular aspirations guided by ultrasound were performed with a minimum interval of 30 days, between May 2006 and July 2008. Recurrent vaginitis was observed, as well as seven episodes of cervical vaginal prolapse during this period. Prolapses were reduced using Bühner suture for 30 days.

On August 2008 the animal showed progressive weight loss and a round-like firm mass of about $6 \mathrm{~cm}$ in diameter with an irregular surface, whitelike color and multifocal red-to-black spots were observed in the vaginal fundus, close to the cervix (Figure 1). An increase in volume was evident on the lateral wall of the vagina, in the areas of traumatism of the vaginal fundus. Histopathological exams of the mass, collected through soft tissues biopsy needle, evidenced tissue of epithelial origin with neoplastic characteristics, forming islets or trabeculae from the superficial to the deep dermis. Neoplastic cells were big and polygonal, with large eosinophilic cytoplasm, round to oval nuclei, loose chromatin and evident nucleoli. Low mitosis was observed and in some regions cell nests showed central keratotic areas of different sizes, leading to a final diagnosis of milddifferentiated SCC.

Two months later, due to the marked weight loss of the animal and increase in the size of the mass (3-fold), surgical removal was chosen. After an epidural anesthesia and preparation of the surgical area, vaginal fundus was pulled craniocaudally to exteriorize the mass through the vulvar lips. In order to reduce the hemorrhage an insulok-tie $(8 \mathrm{~mm} \mathrm{X} 40 \mathrm{~cm})$ was attached at the bottom of the mass and then the tumor was removed. Blood vessels were clamped and obliterated and the borders of the wound

were approximated and sutured using 2-0

Recebido em 10 de junho de 2010

Aceito em 13 de abril de 2011

*Autor para correspondência (corresponding author)

E-mail: zep.filho@hotmail.com 
multifilament absorbable suture. Then, the insulok-tie was removed and vaginal fundus reattached to its original place. Therapy with florfenicol $(20 \mathrm{mg} / \mathrm{kg}$ IM, S.I.D.) and flunixin meglumine $\quad(1.1 \mathrm{mg} / \mathrm{kg} \quad \mathrm{IV}, \quad$ B.I.D. $)$ was implemented. However, five days after the surgery, the cow showed sepsis followed by death. In the necropsy, peritonitis and vesicles containing purulent liquid at the abdominal cavity as well as a quantity of fibrin were found.

Tumor samples were used to assess immunohistochemical evaluation (Figure 2, 3) using the primary antibodies Ki-67 (clone MIB1, DakoCytomation) and p53 (clone CM1, Novocastra). Analysis of the samples was achieved using the image analysis system Image Pro-Leica ${ }^{\circledR}$. Positive and negative nuclei were quantified for a minimum of 1,000 neoplastic cells into 10 fields to determine the percentage of positive cells in the most homogeneous and intensely marked areas.

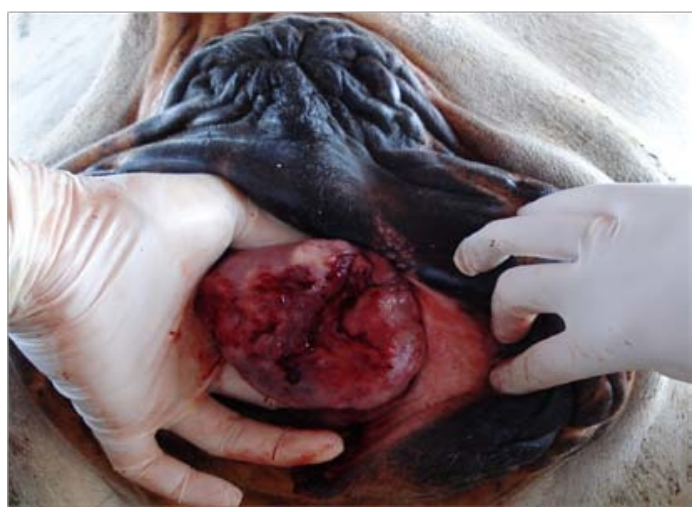

Figure 1. Squamous cell carcinoma in vaginal fundus in a cow two months before surgery.

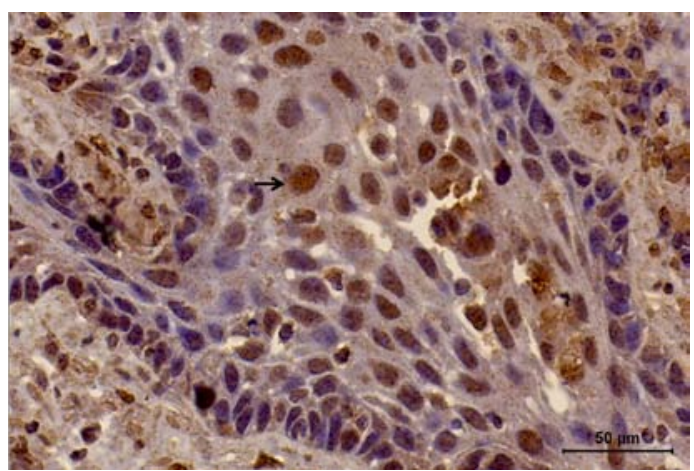

Figure 2. Immunohistochemistry. Nuclear p53 immunoreactivity is seen in the neoplastic cells of tumor island (arrow), 400x.

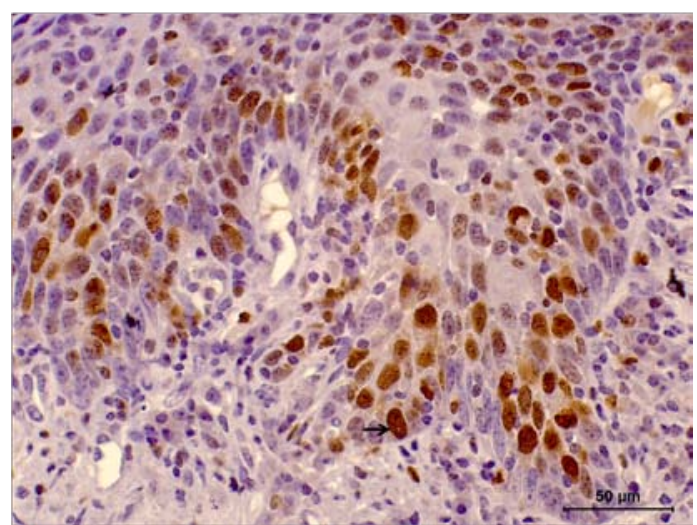

Figure 3. Immunohistochemistry. Positive reaction to Ki67 indicated by the presence of nuclear staining (arrow), 400x.

In recent years, transvaginal follicular aspiration guided by ultrasound in cattle has become a commonly used technique. Nevertheless, repeated transvaginal punctures were associated to cervix lesions, fibrosis of the vaginal fundus, thickening of the lateral wall of the vagina and chronic inflammatory processes (Dória et al., 2008). These findings, also described herein, are different than those in other reports which evidenced a low incidence (5.26\%) of mucosal irritation of the vaginal fundus after consecutive transvaginal punctures, as well as the absence of inflammatory or infectious processes on other regions of the vagina or through the tubular genital tract (Viana et al., 2003). These authors justify the low incidence of inflammatory processes with prophylactic and aseptic techniques and the high capacity of cellular renewal of the vaginal mucosa, associated to the small diameter of the lesion caused by the needle (20G). Although the techniques used for prophylaxis, asepsis, and puncture in this case were as described in previous works, several cases of vaginitis were observed after puncture. Recurrent vaginitis confirmed the findings of other authors, which state that the technique of oocyst collection by ovarian retraction through rectal manipulation, predisposes to irritation and relaxing of the pelvic diaphragm as well as chronic vaginitis, the last potentializing vaginal prolapses due to the increase of expulsive efforts, which justify the recurrent prolapses in this case (Prestes et al., 2008).

The association of chronic inflammatory processes and neoplasms has been richly described (Kusewitt and Rush, 2007). Infection 
and chronic inflammation contribute to $25 \%$ of cancer cases through genetic and epigenetic alterations (Hussain and Harris, 2007). Thus, the chronic inflammatory process in this case probably played a role in the tumor etiology.

Neoplastic epithelial cells on SCC demonstrated variable degrees of squamous differentiation, forming islands, cords or trabeculae in dermis or submucosal associated or not to the proliferation and thickening of the epidermis. Corneal pearls and keratinization of individual cells may occur, so inflammation infiltrate in the neoplastic stroma and a variable degree of desmoplasia may also be found (Ramos et al., 2007). Histopathological findings in this report were similar to those described by other authors.

Different mechanisms may favor neoplasm development; however, all of them lead to DNA mutation into the cell. The last, manifested through increase, diminution or absence of a normal protein expression followed by an expression of abnormal proteins (Kusewitt and Rush, 2007). Positive immunostaining of $23 \%$ for p53 in this tumor is due to a gene mutation (Teifke and Löhr, 1996). The main cellular responses after p53 activation include regulation of the cellular cycle, DNA repairing and apoptosis induction. That is to say that as soon as DNA suffers a mutation, p53 can pause the cellular cycle and repair the DNA. If the damage is very extensive p53 promotes apoptosis (Smith et al., 2003). Nevertheless, when a mutation in the gene for the protein p53 is present, the cell will not suffer apoptosis, which could contribute to uncontrolled cellular proliferation (Gamblin et al., 1997). In many cases of p53 mutation, the protein shows modified conformation and it stores within the nucleus of the tumor cells, making the detection possible through immunohistochemistry (Teifke and Löhr, 1996).

In mild-differentiated SCC, the number of immunomarked cells for Ki-67 may vary between $4.5 \%$ and $26 \%$, with no statistical correlation between histological classification and the number of positive cells (Carvalho et al., 2005). Thus, the percentage of marked cells for Ki-67 found in this case (25.2\%) is compatible with the percentage described in previous works. $\mathrm{Ki}-67$ is a nuclear protein expressed in all active stages of the cellular cycle (G1, S, G2 e M), and absent during the resting state (G0). Therefore, Ki-67 is an excellent marker to determine the proliferation index of a cellular population (Birner et al., 2001). As with p53 (Carvalho et al., 2005), there are only few works on Ki-67 used as a marker of neoplastic proliferation in cattle.

Animals suffering SCC may show a good prognosis whenever surgery is performed at the initial stages of the disease (Galera and Martins, 2001). However, in this report, a bad prognosis was associated to an increase in the size of the mass and cachexia of the patient.

In this case, multiple transvaginal punctures associated to recurrent episodes of vaginitis and vaginal prolapse caused a chronic inflammatory process and probably triggered the SCC. The immunohistochemical markers used were useful to confirm mutation in gene p53 and to evaluate the degree of cell proliferation of the neoplasm.

Keywords: squamous cell carcinoma, equine, immunohistochemistry, p53, Ki67

\section{RESUMO}

É descrito o carcinoma de células escamosas (CCE) no fundo vaginal de uma vaca. O diagnóstico de CCE moderadamente diferenciado foi confirmado através do exame histopatológico. Os testes imunoistoquímicos com os marcadores p53 e Ki67 realizados em amostras do tumor confirmaram a mutação na p53 e aumento da proliferação celular.

Palavras-chave: carcinoma de células escamosas, equino, imunoistoquímica, p53, Ki67 


\section{REFERENCES}

BIRNER, P.; RITZI, M.; MUSAHL, C. et al. Immunohistochemical detection of cell growth fraction in formalin-fixed and paraffin-embedded murine tissue. Am. J. Pathol., v.158, p.19911996, 2001.

CARVALHO, T.; VALA, H.; PINTO, C. et al. Immunohistochemical studies of epithelial cell proliferation and p53 mutation in bovine ocular squamous cell carcinoma. Vet. Pathol., v.42, p.42:66-73, 2005.

DÓRIA, R.G.S.; CANOLA, P.A.; CARDILLI, D.J. et al. Clinical complications in nelore oocyte doners caused by vaginal ultrasound guided follicular aspiration. Cienc. Anim. Bras., v.9, p.806-810, 2008.

GALERA, P.D.; MARTINS, E.A.N. Superficial keratectomy in ocular squamous cells carcinoma in Simmental cattle: A case report. Arq. Bras. Med. Vet. Zootec., v.53, p.585-588, 2001.

GAMBLIN, R.M.; SAGARTZ, J.E.; COUTO, G. Overexpression of p53 tumor suppressor protein in spontaneously arising neoplasms of dogs. Am. J. Pathol., v.58, p.857-863, 1997.

HUSSAIN, S.P.; HARRIS, C.C. Inflammation and cancer: an ancient link with novel potentials. Int. J. Cancer, v.121, p.2373-2380, 2007.
KUSEWITT, D.F.; RUSH, L.J. Neoplasia and tumor biology. In: McGAVIN, M.D.; ZACHARY, J.F. (Eds) Pathologic basis of veterinary disease. St. Louis: Mosby Elsevier, 2007. p.1263-1315.

PRESTES, N.C.; MOYA, C.F.; PIAGENTINI, M. et al. Total or partial vaginal prolapse in the non pregnant cow - is it a new type of pathology? Braz. J. Anim. Reprod., v.32, p.182-190, 2008.

RAMOS, A.T.; NORTE, D.M.; ELIAS, F. et al. Squamous cell carcinoma in cattle, sheep and horse. Study of 50 cases in south of Rio Grande do Sul. Braz. J. Vet. Res. Anim. Sci., v.44, p.513, 2007.

SMITH, N.D.; RUBENSTEIN, J.N.; EGGENER, S.E. et al. The p53 tumor suppressor gene and nuclear protein: basic science review and relevance in the management of bladder cancer. J. Urol., v.169, p.1219-1228, 2003.

TEIFKE, J.P.; LÖHR, C.V. Immunohistochemical detection of p53 overexpression in paraffin wax-embedded squamous cell carcinomas of cattle, horses, cats and dogs. J. Comp. Pathol., v.114, p.205-210, 1996.

VIANA, J.H.M.; NASCIMENTO, A.A.; PINHEIRO, N.L. et al. Characterization of tissue damages after ovum pick-up in bovine. Pesqui. Vet. Bras., v.23, p.119-124, 2003. 